\title{
Korelasi Densitas Relatif Tikus, Pinjal dan Curah Hujan Terhadap Kasus Pes di Daerah Enzootik Pes Taman Nasional Gunung Bromo Tengger, Pasuruan, Jawa Timur \\ (Correlation of Rainfalls, Relative Density of Rats and Fleas Againts Plague Cases in The Plague Enzootic Area, at Mounts of Bromo Tengger National Park, Pasuruan East Jawa)
}

\author{
Ristiyanto, Arief Mulyono, Arum Sih Joharina, Farida Dwi Handayani, Ayu Pradipta, \& Revi \\ Rosavika Kinansih
}

Institute for Vector and Reservoir Control, Research and Development (IVRCRD). National Institute of Health Research and Development, Ministry of Health Indonesia, Salatiga, Indonesia

Email: ristiyanto.salatiga@gmail.com

Memasukkan: September 2020, Diterima: November 2020

\begin{abstract}
Plague Ecological study has been carried out during July to August 2019 in Sulorowo Hamlet, Kayukebek Village, Nongkojajar District (Semeru Bromo Tengger National Park area), Pasuruan Regency, East Java. The study method was tracing surveillance data on bubonic plague in humans (1997-2018), surveillance for rats and fleas, and rainfall (2013-2018). The results showed that in 1997-2018, 82 bubonic plague cases were reported with the number of deaths 21 people, and during 2013-20187 there were 137 bubonic suspects, the number of deaths was 2 people. Rainfall was not significant for the bubonic plague incident. The incidence of suspected bubonic plague was 0.79 times (RR $0.79 ; 95 \%$ CI $(0.74-5.52)$ ) when the relative density of rats in the garden habitat was more than $2 \%$, and the incidence of suspected bubonic plague was 2 times $(\mathrm{p}<0.05 \%$ and $\mathrm{RR} 2.0$; $95 \%$ CI 1.7-2.5) if the general index of fleas in the garden habitat was more than 2 . The relative density of rats and the general index in the home habitat were not significantly related to the incidence of suspected bubonic plague $(p>0.05)$. Low rainfall $(<150 \mathrm{~mm})$ was associated with an increase in the general index of fleas and the relative density of rats in garden habitat $(p<0.05)$. Intensive monitoring in the habitat outside the home (garden) both reservoir hosts, vectors and human activities in the garden should be prepared especially during the dry season to prevent transmission of sylvatic bubonic plague.
\end{abstract}

Keywords: flea index, plague, rat density, silvatic, rainfall.

\begin{abstract}
ABSTRAK
Suatu penelitian ekologis pes telah dilakukan pada bulan Juli-Agustus, 2019 di di Dusun Sulorowo, Desa Kayukebek, Kecamatan Nongkojajar (wilayah Taman Nasional Semeru Bromo Tengger), Kabupaten Pasuruan, Jawa Timur. Metode penelitian yang dilakukan adalah penelusuran data surveilans pes pada manusia (19972018), surveilans tikus dan pinjal, serta curah hujan (2013-2018). Hasil penelitian menunjukkan bahwa pada tahun 1997-2018, dilaporkan 82 kasus pes dengan jumlah kematian 21 orang, dan selama tahun 2013-2018 ditemukan 137 tersangka pes, jumlah kematian 2 orang. Curah hujan tidak bermakna terhadap kejadian tersangka pes. Kejadian tersangka pes 0,79 kali (RR 0,79; 95\% CI $(0,74-5,52)$ ) ketika kepadatan relatif tikus di habitat kebun lebih dari 2\%, dan kejadian tersangka pes 2 kali lipat ( $\mathrm{p}<0,05 \%$ dan RR 2,0;95\% CI 1,7-2,5), apabila indeks umum pinjal di habitat kebun lebih dari 2. Kepadatan relatif tikus dan indeks umum di habitat rumah tidak berhubungan secara bermakna terhadap kejadian tersangka pes $(p>0,05)$. Curah hujan rendah $(<$ $150 \mathrm{~mm}$ ) berhubungan dengan peningkatan indeks umum pinjal dan kepadatan relatif tikus di habitat kebun $(p<0,05)$. Pemantauan secara intensif di habitat luar rumah (kebun) baik inang reservoir, vektor maupun aktivitas manusia di kebun sebaiknya dilakukan terutama pada musim kemarau untuk mencegah penularan pes silvatik.
\end{abstract}

Kata Kunci: indeks pinjal, pes, kepadatan tikus, silvatik, curah hujan.

\section{PENDAHULUAN}

Di Indonesia, pes telah diketahui sejak abad ke dua puluh, tahun 1905, yaitu saat ditemukan beberapa kasus pes di Pantai Timur Sumatera dan 'menghilang' tanpa dilakukan tindakan apapun. Saat ini, abad ke 21, di Pulau Jawa, seperti di Kabupaten Pasuruan, Jawa Timur, Kabupaten 
Boyolali, Jawa Tengah, Kabupaten Sleman, D.I. Yogyakarta dan Kabupaten Bandung, Jawa Barat pes masih perlu diwaspadai (Sub Direktorat Zoonosis 2014). Di keempat kabupaten tersebut, pes dikenal sejak tahun 1911-1970, dan instansi pemerintah berwenang telah melakukan pemantauan dan pengendalian pes secara intensif dan komprehensif. Kegiatan tersebut telah dilakukan sudah lebih dari 50 tahun. Pada tahun 1987, 1997, dan 2007, pes pada manusia, tikus, dan pinjal ditemukan kembali di Kabupaten Pasuruan, Jawa Timur, tetapi di tiga kabupaten lainnya pes tidak terdeteksi lagi secara laboratori (Tarmizi 2019). Saat ini, di Dusun Sulorowo, Desa Kayukebek, Kecamatan Nongkojajar, Kabupaten Pasuruan, Jawa Timur tetap dianggap sebagai daerah yang mendapatkan pengawasan berkaitan dengan penyakit tersebut, karena pernah terjadi lebih dari 2 kali kejadian luar biasa pes.

Pes ditularkan dari tikus ke hewan lain dan atau ke manusia oleh pinjal yang terinfeksi bakteri Yersinia pestis (Perry \& Fetherston. (1997)Menurut Survivalina dkk. (2019), wabah pes tahun 1968-1970, di Kabupaten Boyolali, Jawa Tengah, berawal dari penduduk terjangkit pes setelah beraktivitas di hutan lereng Gunung Merapi. Tikus yang berperan dalam kejadian pes saat itu adalah tikus ladang Rattus exulans, dan tikus rumah $R$. rattus diardii dan pinjalnya Xenopsylla cheopis, Stivalius cognatus, dan Neopsylla sondaica (Turner et al. 1975). Kejadian pes tahun 1997, di Kecamatan Nongkojajar, Kabupaten Pasuruan, Jawa Timur, diawali dengan ditemukannya tikus putih positif terhadap bakteri $Y$. pestis, setelah diinokulasi pinjal tikus rumah Xenopsylla cheopis yang berasal dari tikus rumah $R$. tanezumi (Subronto 2001). Di Kabupaten Boyolali kejadian luar biasa pes diperkirakan dimulai pada musim kering, Agustus 1967, akan tetapi diketahui dengan jelas pada awal tahun 1968 (Januari) dan kasus pes terus ditemukan dari Januari-April 1968 (Survivalina et al. 2019) sedangkan di Kabupaten Pasuruan, Jawa Timur, kasus pes diduga memuncak musim kering, pada bulan JuniJuli 1986 (Subronto 2001). Menurut Pham et al. (2009), di Vietnam, kejadian luar biasa pes sering terjadi di musim kering, Februari-April, saat curah hujan kurang dari $100 \mathrm{~mm}$, dengan faktor risiko terjadi peningkatan indeks pinjal, dan kepadatan tikus. Mamalia yang berperan sebagai sumber penular pes adalah tikus ladang R. exulans, R. nitidus dan cecurut rumah Suncus murinus. Sedangkan pinjal vektor pes utamanya adalah pinjal tikus rumah $X$. cheopis dan pinjal manusia Pulex irritans.

Pham et al. (2009) mengutarakan bahwa faktor ekologi yang berperan dalam kejadian pes adalah musim, kepadatan tikus, dan indeks pinjal. Penelitian pada akhir 1960-an dan awal 1970-an menunjukkan bahwa populasi pinjal bulanan berkorelasi terbalik dengan curah hujan dan bahwa indeks Xenopsylla cheopis pada Rattus rattus meningkat 3 kali lipat pada musim kemarau. Selanjutnya, variasi suhu dan kelembaban relatif di habitat tikus telah terbukti berhubungan dengan perkembangan bakteri pes di dalam tubuh pinjal kejadian Pes (Stenseth et al. 2006).

Hasil program pengendalian pes di Indonesia menunjukkan bahwa pes pada manusia secara laboratoris tidak pernah ditemukan selama 5 dekade, bahkan WHO dan CDC menyatakan bahwa Indonesia merupakan negara dengan faktor risiko rendah terhadap penularan pes, akan tetapi pes tetap perlu diawasi karena, terdapat 'periode hening' (silence periode) pada siklus penularan pes, yaitu pes dapat muncul setelah dorman yang berlangsung berkisar antara 10-60 tahun (Bertherat \& Gage 2019). Artikel ini bertujuan untuk mendeskripsikan lingkungan daerah pes dan analisis faktor ekologi yang terkait dengan kejadian pes, seperti faktor abiotik (curah hujan dan kelembaban) dan biotik (kepadatan pinjal dan tikus) di Dusun Sulorowo, Desa Kayukebek, Kecamatan Nongkojajar, Kabupaten Pasuruan, Jawa Timur. Diharapkan artikel ini dapat digunakan sebagai acuan dalam sistem kewaspadaan dini dan menentukan tindakan pengendalian pes di masa depan.

\section{BAHAN DAN CARAKERJA}

Penelitian ini dilakukan di Dusun Sulorowo, Desa Kayukebek, Kecamatan Nongkojajar, Kabupaten Pasuruan, Jawa Timur pada bulan Juli, 2019. Pada penelitian ini dilakukan penelusuran data surveilans pes di Dinas Kesehatan Kabupaten 
Pasuruan, Jawa Timur meliputi data surveilans pes pada manusia, tahun 1997-2018 dan data surveilans tikus/pinjal, serta data curah hujan dan kelembaban udara di dusun tersebut dari tahun 2013-2018. Kisaran tahun tersebut merupakan data terlengkap untuk curah hujan dan kelembaban udara. Surveilans pes pada manusia, tikus dan pinjal di daerah penelitian dilakukan oleh Puskesmas, dan dilaporkan setiap bulan ke Dinas Kesehatan Kabupaten Pasuruan, Jawa Timur. Surveilans pes dilakukan setiap saat secara pasif dan aktif. Cara surveilans pes sesuai dengan Petunjuk Teknis Pengendalian Pes Dirjen P2PL (Kemenkes 2014). Pengamatan lingkungan dilakukan sesuai dengan Pedoman Riset Khusus Vektor dan Reservoir Penyakit, B2P2VRP, Badan Litbang Kesehatan, Kemenkes R.I., tahun 2017.

Analisis data menggunakan SPSS V.10 (Santosa 2010). Tujuan utama analisis data adalah untuk menentukan kejadian pes dan hubungannya dengan faktor risiko ekologis potensial. Analisis data menggunakan 2 metode yaitu metode bivariate/deskriptif untuk analisis Convidence Interval dan analisis multivariate untuk menentukan Relative Risk (RR) .

\section{HASIL}

\section{Diskripsi Lingkungan Daerah Penelitian}

Wilayah ini dikenal sebagai daerah gigir gunung (punggung pegunungan Sulorowo), daerah Kawasan Hutan Lindung Bromo Tengger, terletak di bagian barat daya $150 \mathrm{~km}$ dari Kota Surabaya (Gambar $1 \mathrm{AB})$.
Dusun ini merupakan daerah pertanian yang subur, dengan tanaman utama apel dan sayuran (kentang, tomat, kobis dan lain-lain). Wilayah ini terpencil dari ibu kota Kabupaten Pasuruan, tetapi dapat dijangkau oleh kendaraan roda empat. Penduduknya $80 \%$ dari 274 jiwa etnis Bromo Tengger. Topografi bergunung-gunung dengan ketinggian rata-rata $1.200 \mathrm{~m}$ di atas permukaan laut. Musim kemarau terjadi pada April hingga Oktober dan musim hujan dari November hingga April (Pasuruan, Kecamatan Tutur dalam Angka 2018). Curah hujan rata-rata adalah antara $2200 \mathrm{~mm}$. Suhu rata-rata tahunan berkisar antara $19-25^{\circ} \mathrm{C}$ (Tabel 1).

\section{Interaksi Kasus Tersangka Pes terhadap Kepadatan Relatif Tikus dan Indeks Pinjal}

Gambar 2 memperlihatkan fluktuasi jumlah tersangka pes pada manusia tahun 1997 hingga 2018. Tersangka kasus pes tahun 2007 relatif paling tinggi dibandingkan dengan pada tahun lainnya, tetapi kematian karena pes tertinggi pada tahun 1987.

Rata-rata angka prevalensi tersangka pes ditemukan pada musim kemarau (FebruariSeptember) dengan puncaknya pada bulan MaretApril (Tabel 2). Analisis univariat mengungkapkan bahwa risiko musim tidak bermakna terhadap kejadian pes, tetapi di sisi lain, kasus pes meningkat 0,79 kali lipat (RR 0,$79 ; 95 \%$ CI $(0,84-5,52)$ ketika kepadatan relatif tikus di habitat kebun meningkat lebih dari $2 \%$, dan 2 kali lipat (RR 2,0; 95\% CI 1,7-2,5) secara bermakna $(\mathrm{p}<0,05 \%)$, ketika indeks umum
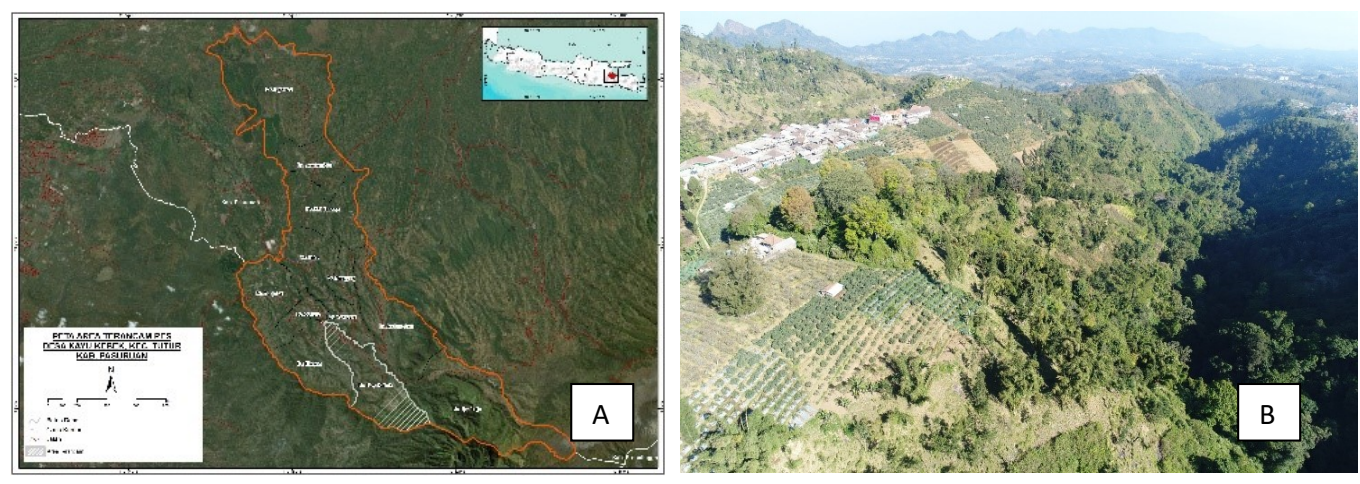

Gambar 1. Peta Dusun Sulorowo, Desa Kayu Kebek, Kecamatan Nongkojajar, Kabupaten Pasuruan, Jawa Timur (A). Foto udara Dusun Sulorowo, Desa Kayu Kebek, Kecamatana Nongkojajar, Kabupaten Pasuruan, Jawa Timur, tahun 2019 (B) 
pinjal di habitat kebun juga meningkat lebih dari 2 (Tabel 3).

\section{Dinamika interaksi kepadatan relatif tikus} dan indeks pinjal terhadap curah hujan

Total semua jenis tikus yang ditangkap tahun 2013-2018 di habitat rumah, 2.838 ekor

Tabel 1. Deskripsi Faktor lingkungan abiotic, Dusun Sulorowo, Desa Kayu Kebek, Kecamatan Nongkojajar, Kabupaten Pasuruan, Jawa Timur

\begin{tabular}{lcc}
\hline \multirow{2}{*}{ Karakteristik } & \multicolumn{2}{c}{ Dusun Sulorowo } \\
\cline { 2 - 3 } & Musim Kemarau & Musim Hujan \\
\hline Rata-rata ketinggian dpl. $(\mathrm{m})$ & $16-25$ & $600-800$ \\
Suhu Udara Luar Rumah $\left({ }^{\circ} \mathrm{C}\right)$ & $20-23$ & $18-27,5$ \\
Suhu Udara Dalam Rumah $\left({ }^{\circ} \mathrm{C}\right)$ & $28 / 2305$ & $22-27$ \\
Rata-rata intensitas cahaya Luar Rumah $(\mathrm{lux}) / \mathrm{h}$ & $20 / 1912$ & $21 / 2213$ \\
Rata-rata intensitas cahaya dalam rumah & $75-80$ & $19 / 1821$ \\
Rata-rata kelembaban musim kemarau & 246,83 & $80-95$ \\
Curah hujan & & 327,83 \\
\hline
\end{tabular}

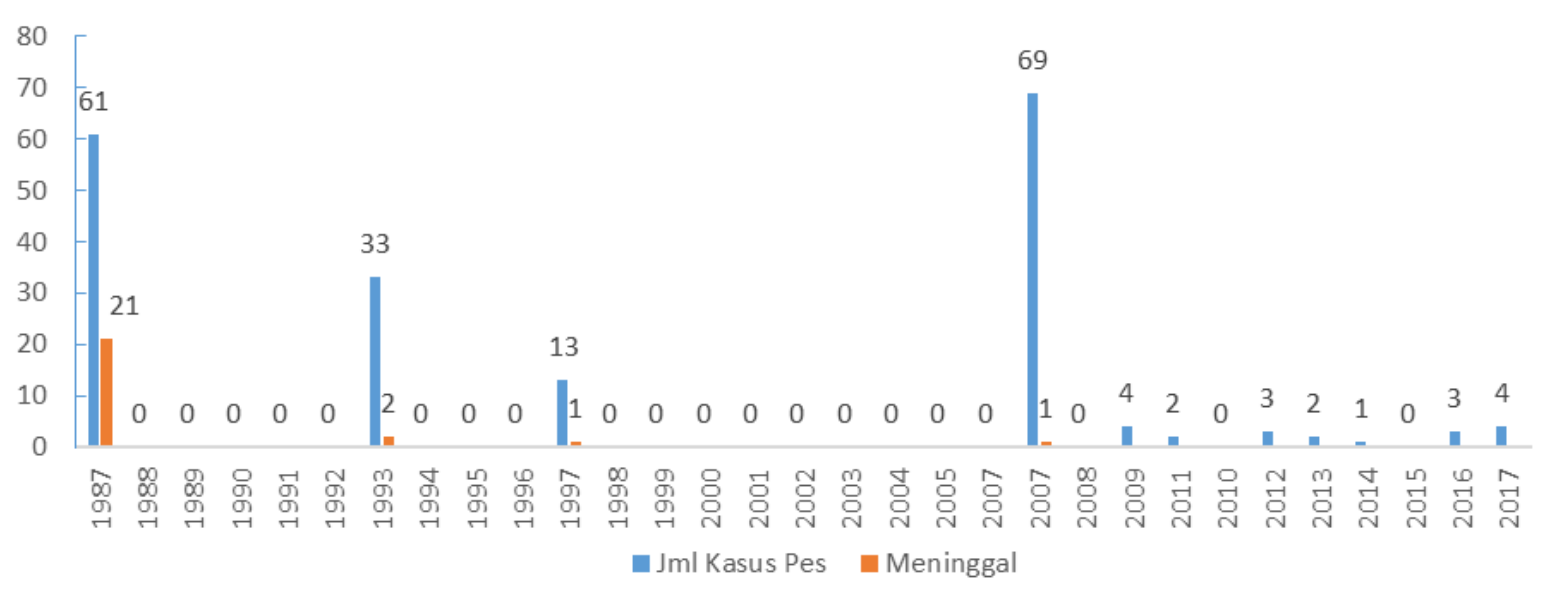

Gambar 2. Dinamika jumlah kasus/tersangka pes di Dusun Sulorowo, Desa Kayu Kebek, Kecamatan Nongkojajar, Kabupaten Pasuruan, Jawa Timur, 1997-2017

Tabel 2. Dinamika faktor abiotik dan kejadian pes di Dusun Sulorowo, Desa Kayu Kebek, Kecamatan Tutur Nongkojajar, Kabupaten Pasuruan, Jawa Timur, 2013-2017 (Sumber data; Surveilans Pes, Dinas Kesehatan Kabupaten Pasuruan, 2013-2017, tidak di publikasikan)

\begin{tabular}{|c|c|c|c|c|c|c|c|}
\hline \multirow[b]{2}{*}{ Tahun/Bulan } & \multicolumn{2}{|c|}{$\begin{array}{c}\text { Kepadatan } \\
\text { Relatif Tikus }\end{array}$} & \multicolumn{2}{|c|}{$\begin{array}{c}\text { Indeks Umum } \\
\text { Pinjal }\end{array}$} & \multirow[b]{2}{*}{$\begin{array}{c}\text { Kelembaban } \\
\text { Udara }(\%)\end{array}$} & \multirow{2}{*}{$\begin{array}{c}\text { Curah } \\
\text { Hujan } \\
(\mathbf{m m})\end{array}$} & \multirow{2}{*}{$\begin{array}{c}\text { Rata-rata angka } \\
\text { Prevalensi Jumlah } \\
\text { Kasus klinis tersangka } \\
\text { pes (demam, bubo) } / 100 \\
\text { orang }\end{array}$} \\
\hline & Rumah & Kebun & Rumah & Kebun & & & \\
\hline Januari & 8,67 & 8,87 & 2,12 & 0,71 & 91,4 & 576,7 & 0 \\
\hline Pebruari & 8,19 & 8,74 & 2,16 & 0,47 & 91,4 & 622,74 & 0,2 \\
\hline Maret & 5,67 & 5,83 & 2,06 & 0,79 & 91,6 & 569,72 & 0,6 \\
\hline April & 5,79 & 6,05 & 2,65 & 0,65 & 90 & 560,14 & 0,4 \\
\hline ei & 6,37 & 6,15 & 2,12 & 0,36 & 87,6 & 335,9 & 0 \\
\hline Juni & 5,20 & 5,01 & 1,75 & 0,48 & 87,4 & 241,36 & 0,2 \\
\hline Juli & 4,73 & 4,99 & 1,64 & 0,84 & 86 & 166,02 & 0,4 \\
\hline Agustus & 5,60 & 5,91 & 2,15 & 0,62 & 81,4 & 74,24 & 0 \\
\hline September & 5,63 & 5,95 & 2,04 & 0,508 & 72,8 & 28,08 & 0,2 \\
\hline Oktober & 4,80 & 4,72 & 2,05 & 0,662 & 72 & 50,14 & 0 \\
\hline November & 5,47 & 5,65 & 2,56 & 0,736 & 82,2 & 318,24 & 0 \\
\hline Desember & 7,00 & 7,03 & 2,77 & 0,868 & 90,8 & 596,46 & 0 \\
\hline
\end{tabular}


dan di habitat kebun, 1.390 ekor meliputi, tikus rumah Rattus tanezumi (83\%), Rattus exulans $(13,6 \%)$ dan Rattus tiomanicus (2,8\%). Serum darah tikus yang diuji $\mathrm{HA} / \mathrm{HI}$ untuk $Y$. pestis, menunjukkan bahwa tidak terkonfirmasi $Y$. pestis.

Selama periode yang sama, diperoleh 4.588 ekor pinjal dari tikus di habitat rumah dan 701 ekor pinjal dari tikus di habitat kebun, meliput $X$. cheopis (97\%), Stivalius cognatus (2,8\%), dan Neopsylla sondaica $(0,2 \%)$. Hasil gerusan pinjal yang diinokulasikan ke mencit putih, tahun 20132018, tidak ditemukan pinjal positif $Y$. pestis.

Berdasarkan model regresi Poisson multi variabel (Tabel 3), peningkatan risiko Pes secara independen terkait dengan indeks umum pinjal ( $<<0,05$ : rasio risiko (RR) 2,0; Interval kepercayaan 95\% (CI) 1,7-2,5). dan kepadatan relatif tikus di habitat kebun $(\mathrm{p}<0,05$ : rasio risiko (RR) 0,79; Interval kepercayaan 95\% (CI) 0,67-7,17.

Curah hujan tidak berpengaruh terhadap kepadatan relatif tikus di habitat rumah $(\mathrm{p}>0,05)$, tetapi ada kecenderungan kepadatan relatif tikus per bulan meningkat secara eksponensial ketika curah hujan turun $<150 \mathrm{~mm}$ (Gambar 3A \& 3B). Sedangkan kepadatan relatif tikus di habitat kebun dipengaruhi curah hujan ( $<<0,05)$, kepadatan relatif tikus menurun secara eksponensial ketika curah hujan lebih dari $150 \mathrm{~mm}$ (Gambar 3C).

Curah hujan tidak bermakna terhadap indeks umum pinjal di habitat rumah $(\mathrm{p}>0,05)$ (Tabel 3; Gambar 4A), dan indeks umum pinjal di habitat rumah cenderung konstan baik ketika

Tabel 3. Dinamika faktor abiotik dan kejadian pes di Dusun Sulorowo, Desa Kayu Kebek, Kecamatan Tutur Nongkojajar, Kabupaten Pasuruan, Jawa Timur, 2013-2017 (Sumber data; Surveilans Pes, Dinas Kesehatan Kabupaten Pasuruan, 2013-2017, tidak dipublikasikan)

\begin{tabular}{llll}
\hline \multicolumn{1}{c}{ Faktor risiko } & \multicolumn{1}{c}{ Variabel } & \multicolumn{1}{c}{ RR } & P-Value \\
\hline Indeks Umum pinjal Rumah & Lebih dari 2 & 0,$79 ; 95 \%$ CI $(0,74-5,52)$ & 0,235 \\
Indeks Umum Pinjal Kebun & Lebih dari 2 & $2.0 ; 95 \%$ CI $(1.7-2.5)$ & 0,013 \\
Kepadatan tikus relatif Rumah & Lebih dari 7\% $\%$, 3,$17 ; 95 \%$ CI $(5,00-7,17)$ & 0,562 \\
Kepadatan tikus relative kebun & Lebih dari 2\% & 0,$79 ; 95 \%$ CI $(0,67-6,63)$ & 0,030 \\
Curah hujan & Kurang dari 150 mm & 7,$9 ; 95 \%$ CI $(5,60-9,98)$ & 0,677 \\
Kelembaban & Bulan Kering versus Bulan basah & 7,$2 ; 95 \%$ CI $(5,9-9,4)$ & 0,423 \\
\hline
\end{tabular}
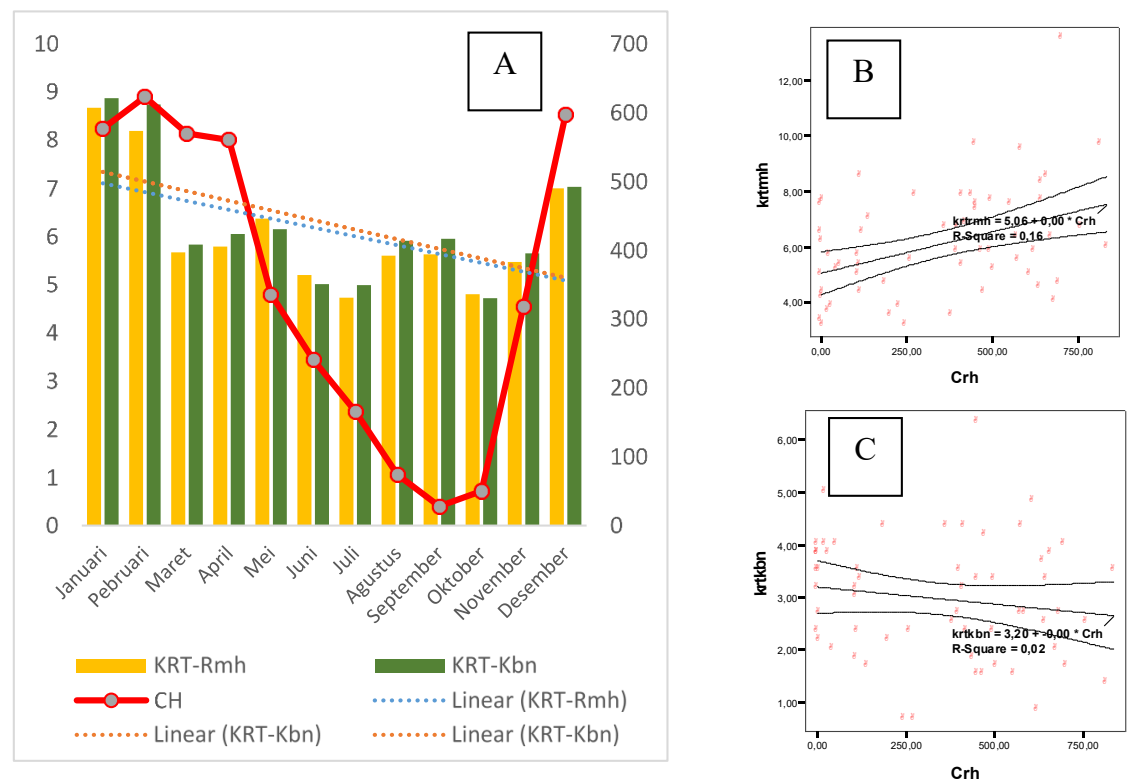

Gambar 3. Fluktuasi kepadatan relatif tikus dan curah hujan di Dusun Sulorowo, Desa Kayu Kebek, Kecamatan Nongkojajar, Kabupaten Pasuruan, Jawa Timur, 2013-2017 (A). Kepadatan relatif tikus di habitat rumah cenderung berbanding lurus ketika curah hujan meningkat (B) dan kepadatan relatif tikus cenderung berbanding terbalik ketika curah hujan meningkat $(C)$. 
curah hujan menurun kurang dari $150 \mathrm{~mm}$ maupun meningkat lebih dari $150 \mathrm{~mm}$ (Gambar 4B). Sedangkan indeks umum pinjal di habitat kebun dipengaruhi oleh curah hujan secara bermakna $(p<0,05)$ (Tabel 3), dan cenderung berbanding terbalik secara eksponensial terhadap curah hujan, yaitu indeks umum pinjal cenderung meningkat apabila curah hujan kurang dari $150 \mathrm{~mm}$ dan menurun jika curah hujan lebih dari $150 \mathrm{~mm}$ (Gambar 4C).

\section{PEMBAHASAN}

Surveilans pes telah dilakukan selama periode 1997-2018. Selama lebih kurang 20 tahun konfirmasi kasus pes, baik secara serologi maupun bakteriologi, tidak ditemukan lagi tetapi secara klinis seperti kasus pembengkakan kelenjar limfa (limfadenitis) masih ditemukan. Menurut Pham et al. (2009), tidak adanya kasus pes terkonfirmasi yang telah berlangsung 10 tahun atau lebih dapat menjadi tanda 'periode hening', yang tetap perlu diwaspadai, setelah periode tersebut secara tiba- tiba dan sulit untuk diprediksi wabah pes dapat terjadi. Periode hening telah diamati di India pada tahun 1994, berdasarkan data kasus pes tahun 1997-2007, tingkat fatalitas kasus pes pasca periode hening di India adalah $0 \%$, yang jauh lebih rendah daripada yang dilaporkan di Vietnam (5\%) dan Madagaskar (20\%) (Stenseth, et al 2006).

Sulit untuk membandingkan tingkat fatalitas antar negara karena perbedaan kondisi lokal dan sistem manajemen pengelolaan/perawatan Kesehatan (WHO 1999ab). Selama periode hening, terdapat kecenderungan jumlah tikus dan pinjal terperangkap lebih rendah dari pada tahun sebelumnya (Pham et al. 2009).

Data surveilans pes di Dusun Sulorowo, Desa Kayukebek, Kecamatan Nongkojajar, Kabupaten Pasuruan, Jawa Timur menunjukkan bahwa pola pes pada manusia di Dusun Sulorowo, Desa Kayukebek, Kecamatan Nongkojajar, Kabupaten Pasuruan, Jawa Timur bervariasi berdasarkan musim, dengan jumlah kasus tersangka pes tahun 2013-2017 (tidak terkonfirmasi pes secara
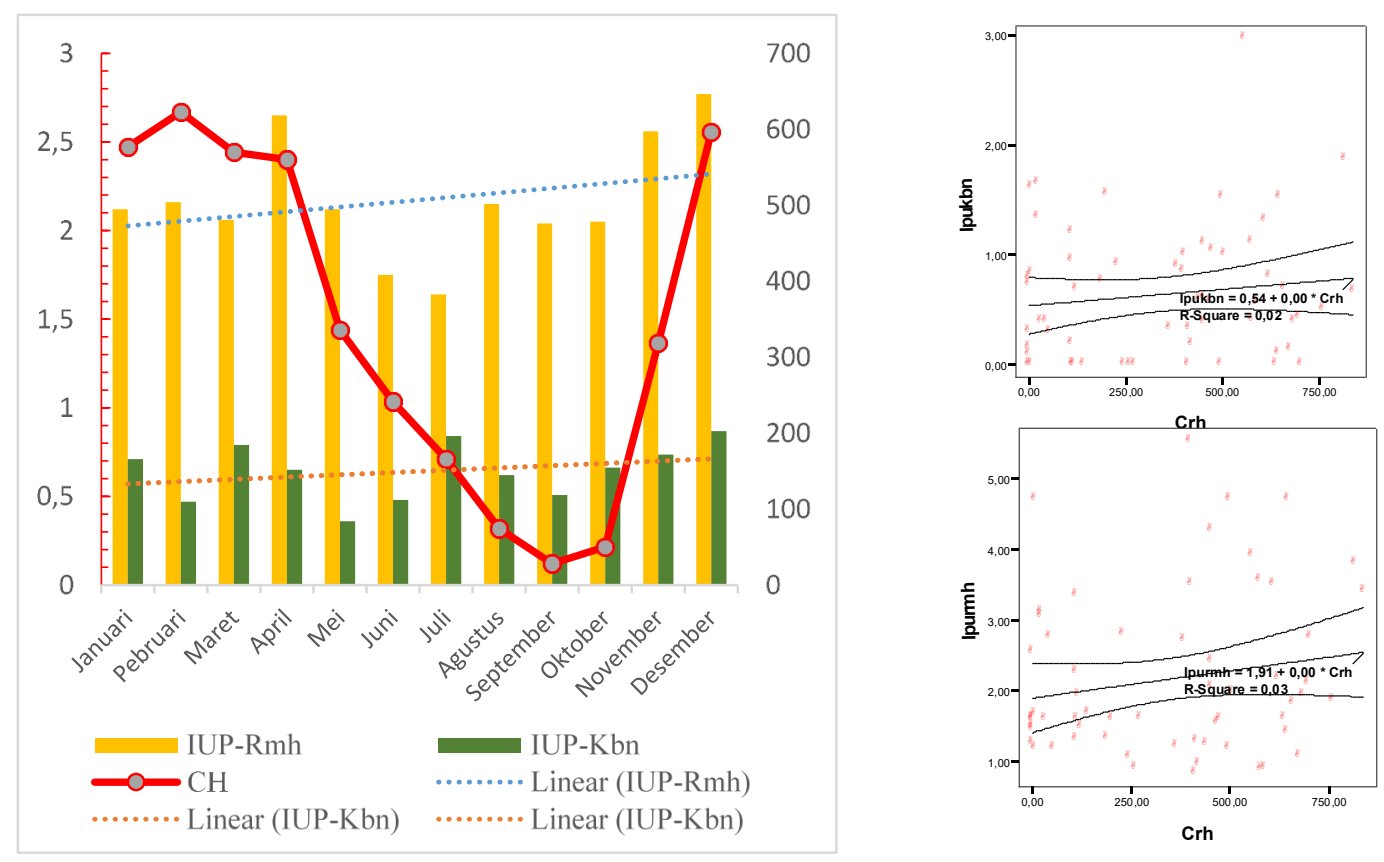

Gambar 4. Fluktuasi indeks umum pinjal dan curah hujan di Dusun Sulorowo, Desa Kayu Kebek, Kecamatan Nongkojajar, Kabupaten Pasuruan, Jawa Timur, 2013-2017 (A). Indeks umum pinjal di habitat rumah cenderung tidak berbeda secara bermakna terhadap volume curah hujan $(p>0,05)(B)$ dan indeks umum pinjal di habitat kebun cenderung berbanding terbalik dengan volume curah hujan curah hujan $(\mathrm{p}<0,05)(\mathrm{C})$. 
bakteriologi) cenderung meningkat pada musim kemarau. Peningkatan kasus tersangka pes pada musim kemarau diduga disebabkan oleh akvitas penduduk di kebun, bersamaan dengan peningkatan populasi tikus dan pinjal, dan siklus penularan pes di antara tikus liar terpelihara di habitat tersebut. Menurut Subronto (1999) dan Survivalina dkk. (2019), kejadian pes di daerah enzootik pes di Kabupaten Pasuruan, Jawa Timur dan Kabupaten Boyolali, terjadi setelah aktivitas penduduk di habitat kebun meningkat pada musim kemarau (Maret-Juli) (Subronto 2001). Hasil penelitian yang dilakukan oleh Pham dkk (2009) di Vietnam menunjukkan bahwa sebagian besar kasus pes ditemukan pada musim kemarau saat curah hujan berkurang. Penurunan curah hujan biasanya diikuti peningkatan populasi tikus dan pinjal, dan perkembangan $Y$. pestis (Enscore et al. 1997).

Di lokasi penelitian ditemukan bahwa pada musim kemarau indeks umum pinjal mengalami peningkatan, terutama di habitat kebun. Peningkatan indeks umum pinjal pada musim kemarau sesuai dengan pengamatan Cavanaugh et al. (1968) di Vietnam bahwa pinjal cenderung berkembang pesat selama musim kemarau. Hasil penelitian Pham et al. (2009) menemukan bahwa indeks umum pinjal menurun secara eksponensial ketika curah hujan bulanan melebihi $100 \mathrm{~mm}$ dan meningkat ketika curah hujan kurang $100 \mathrm{~mm}$. Curah hujan yang tinggi menyebabkan pinjal terinfeksi jamur, bakteri atau virus, atau pinjal tersebut terperangkap dalam liang tikus dan area tempat pakan (Olson 1970; Gage \& Kosoy 2005).

Pada survei tikus, $R$. tanezumi dan $R$. exulans paling banyak tertangkap daripada jenis tikus lainnya. Dengan demikian tampak bahwa kedua jenis tikus tersebut berpotensi dalam siklus penularan di daerah tersebut. Penelitian Turner et al. (1974) di Kabupaten Boyolali, Jawa Tengah menunjukkan bahwa tikus rumah $R$. tanezumi merupakan inang utama yang berpotensi dalam menyebarkan pes dari habitat peridomestik ke domestik dan tikus ladang $R$. exulans telah diketahui sebagai inang pemelihara siklus pes di hutan (habitat peridomestik), karena walaupun jenis tikus ini telah terinfeksi bakteri pes $Y$. pestis, namun diduga jenis tikus ini masih dapat bertahan hidup (Turner et al. 1975) Hasil ini agak berbeda dari penelitian di wilayah pedesaan dataran tinggi di Vietnam, di antara 1.312 ekor tikus yang ditangkap, 29\% adalah tikus ladang $R$. exulans dan $16 \%$ cecurut rumah Suncus murinus (Cavanaugh et al. 1972). Dengan demikian, tampak bahwa reservoir pes di dataran tinggi berbeda dengan wilayah perkotaan, yang didominasi oleh tikus riul $R$. norvegicus, dan tikus rumah $R$. tanezumi (Velimirovic 1972).

Kepadatan relatif populasi tikus di habitat kebun dipengaruhi oleh curah hujan $(p<0,05)$. Pada saat curah hujan tinggi (musim hujan) diikuti dengan pertumbuhan dan perkembangan tanaman yang meningkat, sehingga sumber pakan tikus melimpah. Hipotesis "Trophic Cascade" menyatakan curah hujan yang tinggi menyebabkan pertumbuhan tanaman dan ketersediaan pakan berlimpah menyebabkan peningkatan populasi tikus dan berkorelasi secara bermakna antara curah hujan, indeks pinjal, kepadatan tikus, dan kejadian pes. Cavanaugh et al. 1968; Enscore et al. 2002; Velimirovic 1972).

Kepadatan relatif tikus dan indeks umum pinjal di habitat rumah tidak dipengaruhi oleh curah hujan $(p>0,05)$. Tikus di habitat rumah relatif terlindung dari gangguan faktor alam, baik faktor abiotik (curah hujan, suhu, kelembaban dan lain-lain) dan biotik (predator, vegatasi dan lain-lain). Tikus di habitat rumah $R$. tanezumi dan Mus musculus kurang menyukai air, tahan haus, dan hanya minum jika menemukan air. Populasi tikus di habitat rumah dipengaruhi oleh sarang dan pakan, sedangkan cuaca tidak berpengaruh langsung terhadap perkembangan dan perilaku tikus yang tinggal di habitat rumah (Priyambodo 2003). Sedangkan pinjal tikus rumah Xenopsylla cheopis merupakan ektoparasit pada inang yang bersifat terrestrial dan semi arboreal (Conrad et al. 1968).

Penelitian ini bersifat ekologis dan jumlah kasus pes sangat sedikit, oleh karena itu tidak mungkin untuk membuat kesimpulan tentang hubungan kausatif antara indeks umum pinjal, kepadatan relatif tikus dan kejadian pes pada tingkat individu kasus tersangka pes dan tidak sesuai untuk analisis faktor risiko secara menyeluruh. 


\section{KESIMPULAN DAN REKOMENDASI}

Di daerah pegunungan, Dusun Sulorowo, Desa Kayukebek, Kecamatan Nongkojajar, (wilayah Taman Nasional Semeru Bromo Tengger), Kabupaten Pasuruan, Jawa Timur, pes berisiko 0,79 atau dibulatkan 1 kali lipat (RR 0,79; 95\% CI $(0,74-5,52))$ ketika kepadatan relatif tikus di habitat kebun meningkat lebih dari $2 \%$, dan 2 kali lipat (RR 2.0; 95\% CI 1.72.5). Kasus pes berhubungan secara bermakna $(p<0,05 \%)$, dengan indeks umum pinjal di habitat kebun. Kepadatan relatif tikus dan indeks umum pinjal di habitat kebun berhubungan secara bermakna dengan curah hujan $(<150 \mathrm{~mm})$.

Pemantauan secara intensif di habitat luar rumah (kebun) baik inang reservoir dan vektor pes maupun aktivitas manusia di kebun, terutama pada musim kemarau (April-Oktober) untuk mencegah penularan pes silvatik.

\section{KONTRIBUTOR}

Penulis R, AM, dan ASJ merupakan kontributor utama, sedangkan penulis FDH, AP, dan RSK merupakan kontributor kedua.

\section{UCAPAN TERIMAKASIH}

Kami haturkan terimakasih kepada Kepala Badan Penelitian dan Pengembangan Kesehatan, Kemenkes R.I., Kepala Balai Besar Penelitian dan Pengembangan Vektor dan Reservoir Penyakit Salatiga yang telah memberikan dukungan dalam sarana dan prasaran selama penelitian ini berlangsung. Kepala Dinas Kesehatan Kabupaten Pasuruan, Jawa Timur, Kepala Bidang Pengengendalian Penyakit Menular, Bpk. Agus Eko, SKM, beserta staf, terutama Ibu Ika dan Bpk. Panji. Kepala Puskesmas Nongkojajar, dr. Arief beserta tim zoonosis terutama Sugiarto, Poniran, Kusyanto, Agus, Syamsul, dan lainnya yang tidak dapat disebutkan satu persatu atas bantuan baik fasilitas, transportasi, laboratorium lapangan, dan tenaga.

\section{DAFTAR PUSTAKA}

Bertherat, E \& K. Gage. 2019. Plague in Indonesia: Risk Assesment (Evaluation of the Prevention and control strategy). WHO-US CDC mission. (unpublish)

Cavanaugh DC, HG. Dangerfield, \& DH. Hunter 1968. Some observations on the current plague outbreak in the Republic of Vietnam. American Journal Public Health
Nations Health 58: 742-52.

Cavanaugh DC, \& JD. Marshall, Jr. 1972. The influence of climate on the seasonal prevalence of plague in the Republic of Vietnam. Journal Wild Disease. 8:85-94.

Conrad FG, FR. LeCocq, \& R. Krain 1968. A recent epidemic of plague in Vietnam. Archives of Internal Medicine 122: 193-98.

Enscore RE, BJ. Biggerstaff, \& TL Brown 2002. Modeling relationships between climate and the frequency of human plague cases in the southwestern United States, 1960-1997. American Journal Tropical Medecine Hygiene. 66:186-96.

Gage, KL. \& MY. Kosoy 2005. Natural history of plague: perspectives from more than a century of research. Annual Review Entomology 50:505-28.

Olson, WP. 1970. Rainfall and plague in Vietnam. International Journal Biometeorology 14: $357-60$.

Perry, RD. \& JD. Fetherston 1997. Yersinia pestisetiologic agent of plague. Clinical Microbiology Review 10: 35-66.

Pham, HV., DT. Dang, NNT. Minh, ND. Nguyen \& TV. Nguyen. 2009. Correlates of environmental factors and human plague: an ecological study in Vietnam.

Priyambodo, S., 1995. Pengendalian Hama Terpadu. Penebar Swadaya. Jakarta.

Santoso, S., 2000. SPSS Statistik Parametrik. PT Media Komputindo, Jakarta.

Salam, A. 2018. Kecamatan Tutur Dalam Angka, 2018. BPS Kabupaten Pasuruan, Jawa Timur.

Stenseth NC, NI. Samia, \& H. Viljugrein. 2006. Plague dynamics are driven by climate variation. Procceding Natal Academic Science USA 103:13110-5.

Sub Direktorat Zoonosis. 2014. Pedoman teknis pengendalian pes. Dirjen. P2P kemenkes. R.I., Jakarta.

Subronto, A. 2001. Kejadian Luar Biasa Pes di Kecamatan Nongkojajar, Kabupaten Pasuruan Jawa Timur, tahun 1986-1987. Pertemuan Pes BBTKL, Surabaya

Survivalina, RS., JK. Sherly \& G. Purwoatmojo. 2019. Pes Dalam Perjalanan Waktu. Sebuah Catatan Melawan Lupa Pes setelah 50 Tahun Menyerang Boyolali. Dinas Kesehatan 
Kabupaten Boyolali. Boyolali.

Tarmizi, N. 2019. Kebijakan Pengendalian Pes Di Indonesia. Pertemuan Evaluasi Pengendalian Pes di Indonesia. Esparc Hotel. Yogyakarta.

Turner, RW., S. Martoprawiro \& SA. Padmowirjono, 1974. Dynamics of The Plague Transmission Cycle in Central Java (Ecology of Potential Flea Vectors). Bulletin Peneltian Kesehatan 2 (2): 15-37.

Turner, RW., Soeharto Padmowirjono, \& Supalin Martoprawiro 1975. Dynamics of The Plague Transmission Cycle in Central Java
(Ecology of mammalian host with special reference to Rattus exulans). Bulletin. Peneltian Kesehatan. 3 (1): p 41-71.

Velimirovic B. 1972. Plague in South-East Asia. A brief historical summary and present geographical distribution. Trans Royal Society Tropical Medecine Hygiene 66: 479 -504 .

WHO. 1999. Plague manual: Epidemiology, Distribution, Surveillance and Control. WHO 74, .

WHO. 1999 Manual Epidemiology, Distribution, Surveillance and Control. 
